\title{
Stable isotope and gas properties of two climatically contrasting (Pleistocene and Holocene) ice wedges from Cape Mamontov Klyk, Laptev Sea, northern Siberia
}

\author{
T. Boereboom ${ }^{1}$, D. Samyn ${ }^{1, *}$, H. Meyer ${ }^{2}$, and J.-L. Tison ${ }^{1}$ \\ ${ }^{1}$ Laboratoire de Glaciologie, Université Libre de Bruxelles, Brussels, Belgium \\ ${ }^{2}$ Alfred Wegener Institute for Polar and Marine Research, Research Unit Potsdam, Potsdam, Germany \\ *now at: Department of Mechanical Engineering, Nagaoka University of Technology, Nagaoka, Japan \\ Correspondence to: T. Boereboom (thierry.boereboom@ulb.ac.be)
}

Received: 30 November 2011 - Published in The Cryosphere Discuss.: 21 December 2011

Revised: 26 November 2012 - Accepted: 28 November 2012 - Published: 4 January 2013

\begin{abstract}
This paper presents and discusses the texture, fabric, water stable isotopes $\left(\delta^{18} \mathrm{O}, \delta \mathrm{D}\right)$ and gas properties (total gas content, $\mathrm{O}_{2}, \mathrm{~N}_{2}, \mathrm{Ar}, \mathrm{CO}_{2}$, and $\mathrm{CH}_{4}$ mixing ratios) of two climatically contrasted (Holocene vs. Pleistocene) ice wedges (IW-26 and IW-28) from Cape Mamontov Klyk, Laptev Sea, in northern Siberia. The two ice wedges display contrasting structures: one being of relatively "clean" ice and the other showing clean ice at its centre as well as debris-rich ice on both sides (referred to as "ice-sand wedge"). Our multiparametric approach allows discrimination between three different ice facies with specific signatures, suggesting different climatic and environmental conditions of formation and various intensities and nature of biological activity. More specifically, crystallography, total gas content and gas composition reveal variable levels of meltwater infiltration and contrasting contributions from anaerobic and aerobic conditions to the biological signatures. Stable isotope data are drawn on to discuss changes in paleoenvironmental conditions and in the temporal variation of the different moisture sources for the snow feeding into the ice wedges infillings. Our data set also supports the previous assumption that the ice wedge IW-28 was formed in Pleistocene and the ice wedge IW-26 in Holocene times. This study sheds more light on the conditions of ice wedge growth under changing environmental conditions.
\end{abstract}

\section{Introduction}

Ice wedges are found inside permafrost areas in the Northern Hemisphere and are widespread in Alaska, Canada and Siberia. The analysis of ice wedge properties is therefore commonly used to provide proxy-data for paleoclimatic and paleoenvironmental reconstructions. First, the isotopic signature $\left(\delta^{18} \mathrm{O}\right.$ or $\left.\delta \mathrm{D}\right)$ of the ice is thought to reflect the isotopic characteristics of the winter precipitation, which is a function of the temperature at the site (Dereviagin et al., 2002; Lauriol et al., 1995; Meyer et al., 2002a, b; Raffi et al., 2004; Vaikmäe, 1989; Vasil'chuk and Vasil'chuk, 1998). As an example, Opel et al. (2011) observed recent ice wedges in northeast Siberia showing $\delta^{18} \mathrm{O} / \delta \mathrm{D}$ values between $-25 \%$ ol $-190 \%$ and $-20 \%$ ol $-140 \%$, while Wetterich et al. (2008) described young Holocene ice wedges with values ranging between $-26 \%$ ol $-195 \%$ and $-22 \%$ o $-175 \%$ and older Holocene ice wedges with values ranging between $-26 \%$ ol $-202 \%$ to $-24 \%$ ol-190\%o. The Pleistocene isotopic signature in the same area clearly differs with values lower by approximately $5 \%$ and $35 \%$ in $\delta^{18} \mathrm{O}$ and $\delta \mathrm{D}$, respectively (Popp et al., 2006) showing $\delta^{18} \mathrm{O} / \delta \mathrm{D}$ values between $-33 \%$ ol $-250 \%$ and $-31 \%$ ol $-245 \%$ (Wetterich et al., 2008) with minima from the Last Glacial Maximum $(-35 \%$ ol $-290 \%$ ) as documented in a recent overview by Wetterich et al. (2011).

Co-isotopic approaches use the deuterium excess $(d)$ as a tracer for changes in the atmospheric source. For example, Meyer et al. (2010b), who identified the Younger Dryas cold event in northern Alaskan ice wedges, also brought to light 
a rapid reorganization of the Arctic atmospheric circulation following the opening of the Bering Strait, with $d$ transitions from about $6 \%$ to about $9 \%$.

Other ice wedge properties can help to understand and reconstruct the environmental condition prevailing during ice wedge genesis. St-Jean et al. (2011) recently used ice crystallography, bubble content, gas composition and stable $\mathrm{O}-\mathrm{H}$ isotopes of ground ice to identify contrasting genetic processes between ice wedges formed during the Late Pleistocene period under cold and dry climatic conditions and ice wedges formed during the Holocene in warmer and wetter conditions. Ice wedge formation primarily results from cyclic (not necessarily each year) frost-cracking and crack infilling by ice (e.g. Mackay, 1974). The cracking results from the thermal contraction of the soil during the winter (Lachenbruch, 1962), and the origin of the ice infilling can be attributed to several sources (or mixture of sources) such as (a) unmodified winter snow, (b) hoarfrost accretion during winter and (c) snow melt infiltration in spring, subsequently refreezing in the crack to form "ice veins" (e.g. Lauriol et al., 1995; Opel et al., 2011; St-Jean et al., 2011). In their work, St-Jean et al. (2011) contrast a Pleistocene ice wedge in which the ice filling results from dry snow compaction or hoarfrost accretion and an Holocene ice wedge in which liquid water infiltration and refreezing dominates.

Ice wedges incorporate variable amounts of sediment depending on the sediment, snow and/or water availability at a given time. Frost cracks can be completely filled by blown sediments in very dry conditions forming a "sand wedge" (e.g. Berg and Black, 1966) or can be filled in by successive ice veins and sediment layers as described in Meyer et al. (2002a) and in Romanovsky (1976). This latter type of structure will be here referred to as an "ice-sand wedge" (also termed "composite wedge").

In this paper, we propose a multi-parametric approach including stable isotope composition, total gas content, gas composition, as well as textures and fabrics to study two specific ice wedges from the Laptev Sea region. These two ice wedges were sampled from a cliff in the framework of the project "Process studies of permafrost dynamics in the Laptev Sea", which aimed to address the paleoenvironmental history of the Cape Mamontov Klyk area (Bobrov et al., 2009; Müller et al., 2009; Schirrmeister et al., 2008). These specific ice wedges were chosen for this study due to their contrasting ages (Holocene vs. Pleistocene) as indicated by their stable isotope signature and stratigraphic position in a dated regional sequence. The aim of the study is two-fold: (a) to improve our knowledge of the imprint of the contrasted Holocene/Pleistocene climatic and environmental conditions on the ice wedge properties and infilling processes and (b) to interpret the specific deuterium excess signature of the two ice wedges in terms of potential changes in atmospheric moisture sources.

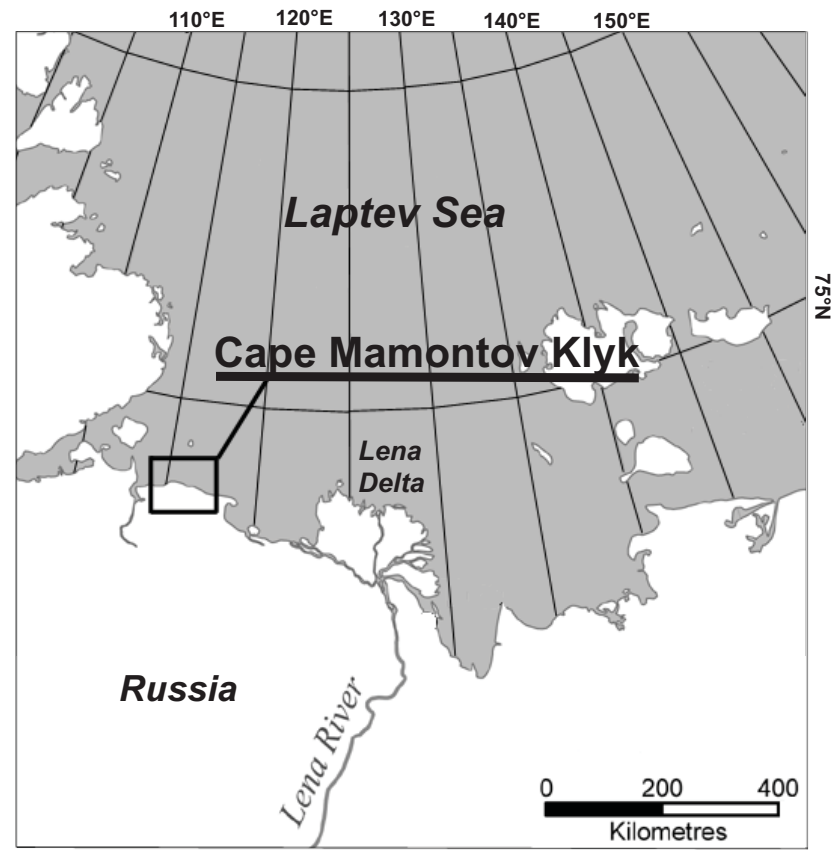

Fig. 1. Location of the Cape Mamontov Klyk sampling site in Arctic Siberia. The studied ice wedges were exposed on a coastal cliff on the Laptev Sea coast.

\section{Study area and ice wedge description}

The two studied ice wedges are part of a coastal bluff on the Laptev Sea coast, about $300 \mathrm{~km}$ west from the Lena Delta $\left(73^{\circ} 36^{\prime} \mathrm{N}, 117^{\circ} 10^{\prime} \mathrm{E}\right.$; Fig. 1). This area belongs to the subarctic tundra in a region of continuous permafrost, with a thickness of 400-600 $\mathrm{m}$ (Yershov, 1989). The active layer shows a maximum thaw depth of $0.2-0.5 \mathrm{~m}$ in July. The area is dominated by a continental Arctic climate with long severe winters.

The cliff from which the ice wedges originate is subdivided into four different sedimentological units (A to $\mathrm{D}$, from old to young; Fig. 2a) and described in detail by Schirrmeister et al. (2008). From the bottom of the cliff to its top, we distinguish a lower sand unit (unit A) that consists of yellowishgrey, irregularly laminated, fine-grained sand, lacking visible plant remains. Grass roots in the uppermost horizon of this unit were dated to $44.5 \mathrm{kyr}$ (Schirrmeister et al., 2008). Above, unit B consists of an alternation of four cryoturbated peat-rich horizons and irregularly laminated, dark-grey silty to fine-grained sandy interbeds. Unit $\mathrm{C}$ is known as "ice complex", a type of ice-rich permafrost deposit of Late Pleistocene age widespread in Arctic Siberia attributed at this site to the Sartan period (Schirrmeister et al., 2008). The ice complex deposits are composed of alternating mineral-rich (greyish) and organic-rich (brownish) sediment layers. The upper unit (unit D) consists of peat soils of Holocene age originating from fillings of small thermokarst or polygonal ponds 


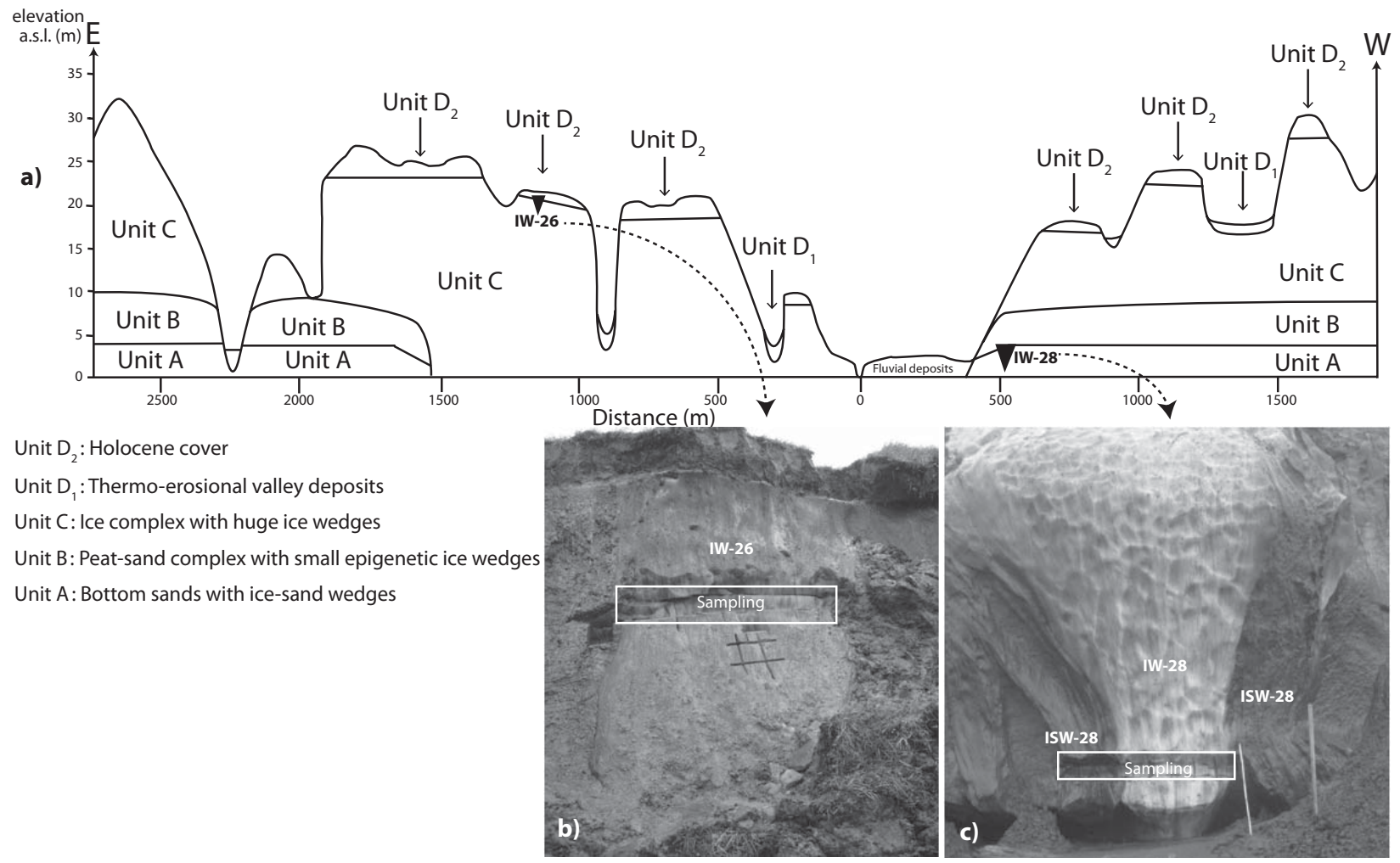

Fig. 2. (a) General stratigraphic scheme of the main section of Mamontov Klyk (adapted from Schirrmeister et al., 2008) with positions and general settings of ice wedges 26 (IW-26) (b) and 28 (IW-28) (c) respectively. The sampling areas are outlined with white boxes, on approximately $160 \mathrm{~cm}$ and $190 \mathrm{~cm}$ for respectively IW-26 and IW-28. Rectangular parallelepipeds have been removed from the cliff with chainsaw of which the upper part $(1.5 \mathrm{~cm}$ thickness $)$ has been used in this work. Note that IW-28 was sampled in both the ice-sand wedge (ISW-28, left of box) and in the ice wedge itself (IW-28, right of box).

developed on top of the ice complex or from Holocene thermoerosional or fluvial deposits.

Ice wedge 26 (IW-26, Fig. 2b) was sampled within unit C in the upper part of the cliff, at $18.6 \mathrm{~m}$ above sea level, and is therefore embedded within late Pleistocene ice complex sediments (Schirrmeister et al., 2008). IW-26 is about $1.6 \mathrm{~m}$ in width, and about $2.5 \mathrm{~m}$ in height are visible. Sampling was performed across the full ice-wedge width, approximately $1.2 \mathrm{~m}$ below the surface. The ice samples consisted of foliated grey to white, and in parts yellowish, ice with small (millimetric) gas bubbles. The wedge ice shows a low content of mineral particles and organic matter (fine-dispersed individual particles or thin layers following the foliation).

The second ice wedge studied in this paper, IW-28 (Fig. 2c), has been attributed to unit A in the lower part of the cliff and was sampled at $1 \mathrm{~m}$ above sea level. It developed in sandy sediments. IW-28 is up to $5 \mathrm{~m}$ wide in its upper part at the top of the cliff. The ice wedge is laterally associated with an ice-sand wedge (ISW-28), a portion of which was also sampled (Fig. 2c, left of sampling box). In the central section, the wedge ice has a white and milky appearance, and small millimeter-sized gas bubbles are frequent (Fig. 3d). The mineral content and the organic matter contents are both low, with particle dispersion similar to that in IW-26 and foliation layers that are $1-3 \mathrm{~mm}$ wide. For the ice-sand wedge portion, the ice is mixed with a significant amount of finegrained sediments alternating with clean ice layers.

\section{Sampling and analytical methods}

The ice wedges were sampled as ice blocks using a chainsaw, in horizontal transects covering the entire ice-wedge width and partly including the ice-sand wedge section from now on referred to as ISW-28 (Fig. 2c). Samples used in this paper for fabric, texture, gas and stable isotope analyses are derived from horizontal sections $( \pm 1.5 \mathrm{~cm}$ thickness $)$ in the top part of the blocks extracted from the ice wedge.

Horizontal thin sections were prepared using a traditional biological microtome (Leitz 1400) for the clean ice and a diamond wire saw (Well 6234) for the debris-laden ice, following the standard procedures from Langway (1958) and Tison (1994), respectively.

Crystal-size determination was performed using two different techniques. The first was the mean linear intercept method developed by Pickering (1976). The number of grain 

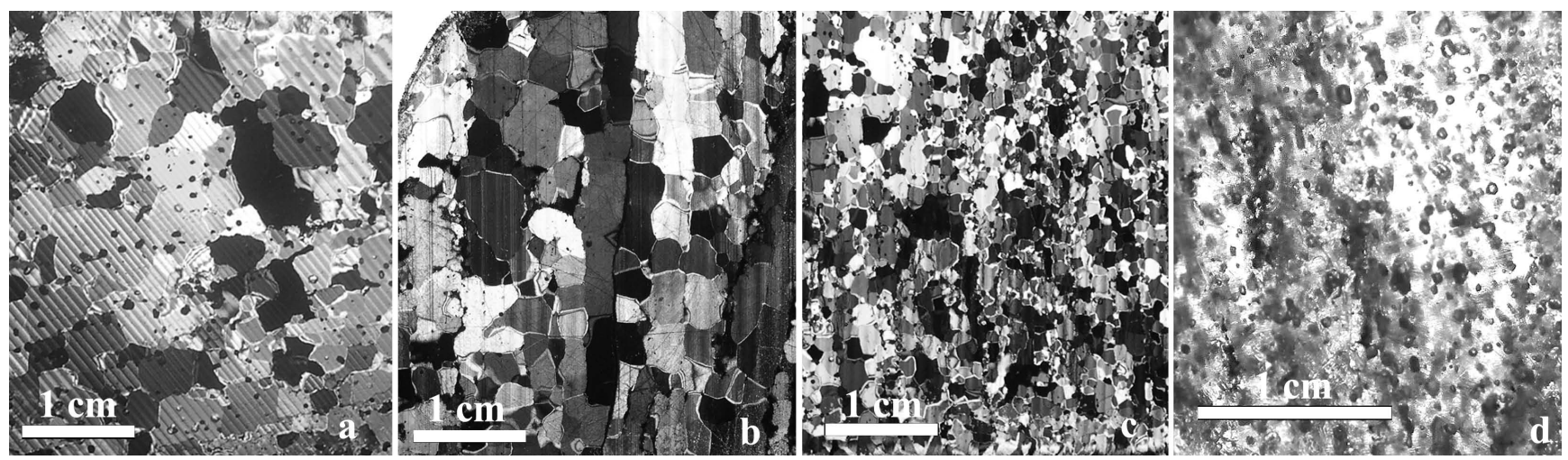

Fig. 3. Thin section photographs of ice wedge texture: (a) IW-26; (b) ISW-28 (ice-sand wedge), the left part of ice wedge 28 with debris subvertical layers (note the crystal elongation along the foliation); (c) IW-28, clean ice in the central part of ice wedge 28; and (d) thick section photograph of ice from IW-28 in transmitted light allowing bubble content observation.

boundaries $(\bar{N})$ crossed by a random linear traverse of length $(\bar{L})$ across the thin section was averaged over many traverses. The mean grain diameter $(\bar{d})$ was estimated using the following equation: $\bar{d}=\bar{N} / \bar{L}$. The second method, proposed by Jacka (1984), estimates the mean diameter by counting the number of entire crystals in a known area and assuming a circular cross-section following the equation $\bar{d}=\sqrt{4 A} / \pi N$, where $A$ is the area of thin section studied and $N$ is the crystal count.

Stable water isotopes were measured at high resolution (approximately every centimeter) with a Finnigan MAT Delta-S mass spectrometer at the Alfred Wegener Institute, Research Unit Potsdam, using equilibration techniques. Hydrogen and oxygen isotope ratios are presented as per mil difference relative to V-SMOW (\%o, Vienna Standard Mean Ocean Water), with internal $1 \sigma$ errors better than $0.8 \%$ and $0.1 \%$ ofor $\delta \mathrm{D}$ and $\delta^{18} \mathrm{O}$, respectively (Meyer et al., 2000).

Gas inclusions entrapped in the ice were analysed for their total gas volume (27 samples) and gas composition $\left(\mathrm{CO}_{2}\right.$, $\mathrm{O}_{2}, \mathrm{~N}_{2}$, Ar, and $\left.\mathrm{CH}_{4}\right)$. Gas composition $\left(\mathrm{CH}_{4}=24\right.$ samples, $\mathrm{Ar}=7$ samples, other gases $=30$ samples) was measured by gas chromatography (Interscience Trace GC) using an FID (flame ionization detector) for $\mathrm{CO}_{2}$ and $\mathrm{CH}_{4}$ and a TCD (thermal conductivity detector) for $\mathrm{O}_{2}, \mathrm{Ar}$ and $\mathrm{N}_{2}$. Between 20 to $35 \mathrm{~g}$ of sample were used for each measurement. For $\mathrm{CO}_{2}, \mathrm{O}_{2}, \mathrm{Ar}$ and $\mathrm{N}_{2}$, we used the dry-extraction technique described in Raynaud et al. (1982) and Barnola et al. (1983). For $\mathrm{CH}_{4}$, we used the melting-refreezing procedure described in Raynaud et al. (1988) and Blunier et al. (1993). The levels of precision of the measurements are $2.5 \%$ for $\mathrm{CO}_{2}, 0.4 \%$ for $\mathrm{O}_{2}$ and $\mathrm{N}_{2}, 2 \%$ for $\mathrm{Ar}$ and $3 \%$ for $\mathrm{CH}_{4}$. The total gas content (27 samples) was determined using a Toepler pump and a melting-refreezing extraction technique described in Martinerie et al. (1994). The precision of the measurements is $\leq 5 \%$.

The limited amounts of ice provided for the gases and fabrics analyses did not yield enough material to perform a full granulometric analysis of the sediment inclusions, which is nevertheless beyond the scope of this paper. At a later stage of the interpretation, however, the residual sediments collected after the gas analyses have been treated by $\mathrm{HCl}$ $\left(1 \mathrm{~mol} \mathrm{~L}^{-1}\right)$ and $\mathrm{H}_{2} \mathrm{O}_{2}(30 \%)$ for qualitative detection of calcium carbonate or organic matter, respectively.

\section{Results}

\subsection{Stable ${ }^{18} \mathrm{O}$ and ${ }^{2} \mathrm{H}$ isotopes}

Ice wedge IW-26 shows $\delta^{18} \mathrm{O}$ values ranging between $-22.6 \%$ and $-25.8 \% o$ and $\delta \mathrm{D}$ values between $-170 \%$ and $-191 \%$, respectively (Fig. 4a). The IW-26 samples plot on a slope of 6.63 in the $\mathrm{D}^{18} \mathrm{O}$ diagram (Fig. 4c, grey squares). The isotopic composition of ice wedge IW-28 is also shown in Fig. 4a, and a clear distinction has to be made between the two different facies of the ice wedge: the ice-sand wedge (ISW-28) and the ice wedge itself (IW-28). These differ both in terms of deuterium excess (Fig. 4b) and co-isotopic relationship (Fig. 4c). The ice-sand wedge ISW-28 displays $\delta^{18} \mathrm{O}$ values between $-29 \%$ and $-30.9 \%$ and $\delta \mathrm{D}$ values between $-230 \%$ and $-246 \%$. The samples show a low variability in $d(1 \sigma= \pm 0.6 \%)$ with a mean value of $1.4 \%$, and they are aligned on a slope of 8.03 in the co-isotopic plot. For the ice wedge part IW-28, $\delta^{18} \mathrm{O}$ and $\delta \mathrm{D}$ range between $-29.4 \%$ and $-31.9 \%$, and between $-229 \%$ and $-247 \%$, respectively. The $d$ also shows a low variability $(1 \sigma= \pm 0.7 \%$ o with a mean value of $7.5 \%$, and a slope of 7.44 is measured in the co-isotopic diagram. The transition has $\delta^{18} \mathrm{O}$ values between $-29.5 \%$ and $-29.9 \%$, a $\delta \mathrm{D}$ between $-223 \%$ and $-237 \%$, and shows variable $d$ values intermediate between the other two parts (Fig. 4c). 

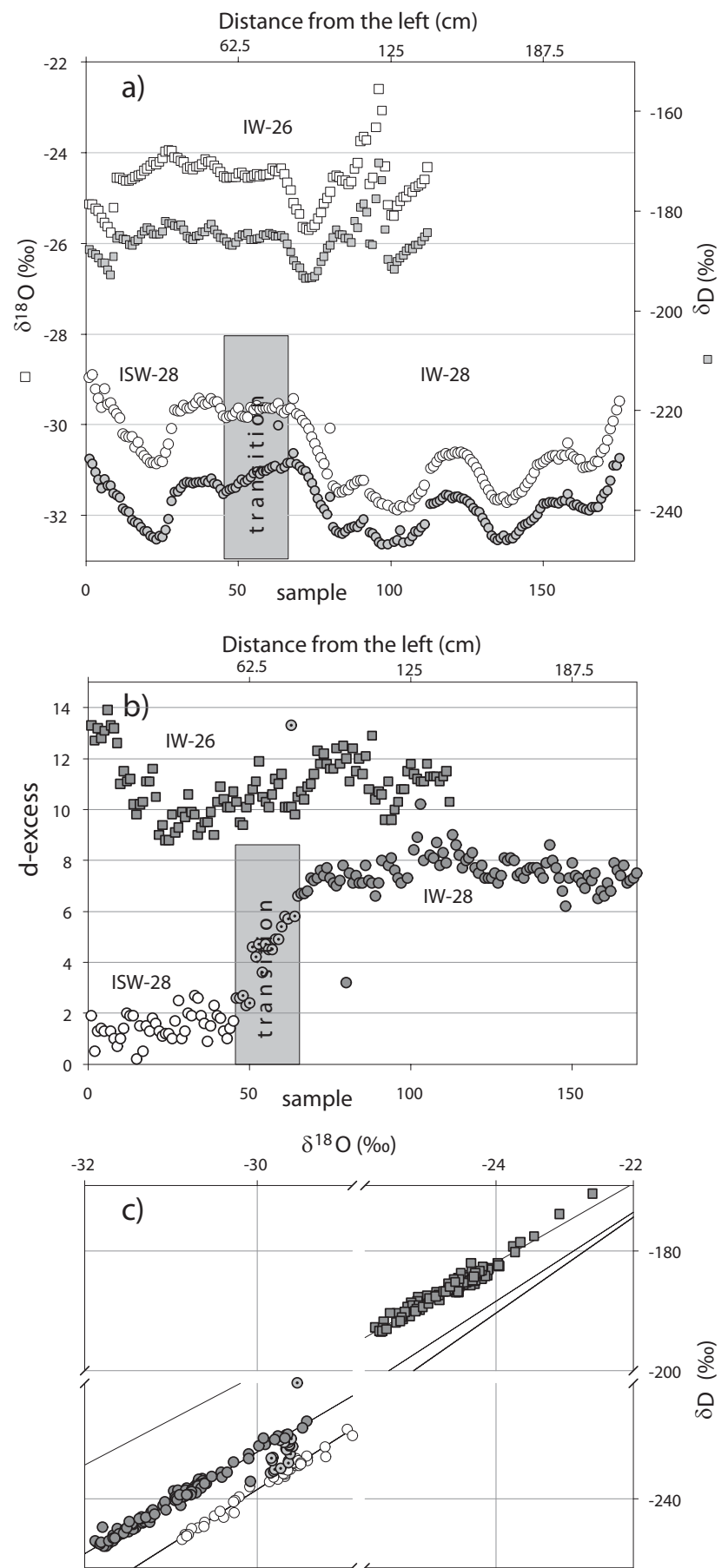

․ IW-26 $\left(\mathrm{S}=6.63 ; \mathrm{d}\right.$ intercept $\left.=-22.88 ; \mathrm{r}^{2}=0.94\right)$

- ISW-28 $\left(\mathrm{S}=8.03 ; \mathrm{d}\right.$ intercept $\left.=2.22 ; \mathrm{r}^{2}=0.98\right)$

$\odot \quad$ Transition zone ISW-28/IW-28

- IW-28 $\left(\mathrm{S}=7.44 ; \mathrm{d}\right.$ intercept $\left.=-9.89 ; \mathrm{r}^{2}=0.98\right)$

Fig. 4. Isotopic data for the two ice wedges: (a) $\delta^{18} \mathrm{O}$ and $\delta \mathrm{D}$ profiles, (b) $d$ and (c) $\delta^{18} \mathrm{O}-\delta \mathrm{D}$ relationship. Numbers on the bottom $\mathrm{x}$-axis of (a) and (b) refer to ice sample ordering, increasing from left to right, in the outcrop. The equivalent horizontal distance from extreme left is shown on the upper $\mathrm{x}$-axis.

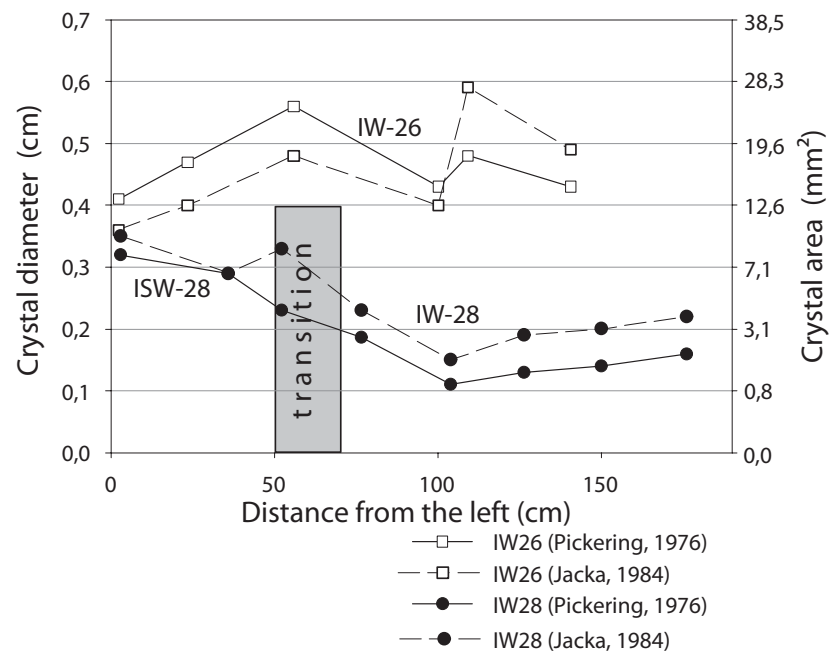

Fig. 5. Crystal size measurements using the two techniques described in the "sampling and analytical methods" section.

\subsection{Ice texture and fabrics}

Figure 3 shows thin section photographs that are typical of the three main facies encountered in the two studied ice wedges. In IW-26, the texture is homogeneous, lacking any significant elongation (Fig. 3a). The crystal diameter is ranging between 0.40 and $0.60 \mathrm{~cm}$ (10 to $30 \mathrm{~mm}^{2}$, Fig. 5), and caxis orientations are concentrated in the horizontal plane with preferred orientation perpendicular to the foliation azimuth (Fig. 6a). The ISW-28 texture shows, within a matrix of relatively large equigranular grains, several monocrystalline layers of elongated crystals with a well-developed "ribbon structure" and crystal growth being geometrically associated with the fine debris layers that surround them, oriented parallel to the (subvertical) foliation plane (Fig. 4b). In Fig. 5, crystal diameter is ranging between 0.2 and $0.4 \mathrm{~cm}\left(3\right.$ to $\left.10 \mathrm{~mm}^{2}\right)$. In IW-28, the central part of the ice wedge shows an equigranular texture (Fig. 4c), with crystals smaller than in ISW-28 (0.1 to $0.2 \mathrm{~cm}-1$ to $3 \mathrm{~mm}^{2}$, Fig. 5). Both ISW-28 (Fig. 6b) and IW-28 (Fig. 6c) show c-axes orientation patterns similar to IW-26, although the preferred orientation perpendicular to the foliation azimuth is less obvious for ISW-28 given the limited number of observations (due to larger grains).

\subsection{Gas properties}

The contrast between the three facies (IW-26, ISW-28 and IW-28) is also evident from their gas properties (Fig. 7). Table 1 summarizes minimum, mean and maximum values observed for the three facies. Total gas contents in our ice wedges are lower than in ice resulting from simple snow compaction as in ice sheets (see ranges in Table 1), and the total gas content of IW-28 is higher than those of ISW28 and IW-26. For $\mathrm{CO}_{2}$, all ice wedge mixing ratios are clearly higher than the atmospheric values, the highest values 
being observed in IW-26 (mean $=62000 \mathrm{ppmV}$ ) and ISW28 showing lower values (mean $=3000 \mathrm{ppmV}$ ) than IW-28 $($ mean $=25000 \mathrm{ppmV})$. On the contrary, $\mathrm{CH}_{4}$ mixing ratios show their lowest values in IW-26 with values in the range of atmospheric mixing ratio (mean $=1 \mathrm{ppmV})$, intermediate values for IW-28 (mean $=8 \mathrm{ppmV}$ ) and the highest values in ISW-28 $($ mean $=55 \mathrm{ppmV})$. Oxygen shows consistently lower values than the atmosphere (of the order of $10 \%$ ), and nitrogen is slightly higher, balancing other constituents.

\subsection{Sediment properties}

Residual sediments collected from four ice samples have been treated with $\mathrm{HCl}$ and $\mathrm{H}_{2} \mathrm{O}_{2}$ (two samples from ISW28 and two samples from IW-28). The ISW-28 samples have strongly reacted with $\mathrm{H}_{2} \mathrm{O}_{2}$ while the IW-28 samples only showed a very limited reaction. We therefore argue that there is organic matter in the ISW-28 sediment inclusions, but only limited amounts in IW-28. On the other hand, the $\mathrm{HCl}$ treatment did not show detectable bubbling activity under the microscope for any of the four sediment samples treated, supporting that carbonate contents are negligible within the sediment enclosed in our ice wedges.

\section{Discussion}

In this section we rely on the ice characteristics (crystallographic properties, gas content and composition and isotopes) to extract information about the environmental conditions governing formation and deposition of ice and to evaluate potential post-genetic alterations of ice wedges.

\subsection{Ice wedge infilling processes}

In this section we use ice characteristics (crystallographic properties, gas content and composition and isotopes) and the knowledge of the signification of these characteristics on the condition of the ice formation. Indeed, the ice properties are the reflection of the ice formation process and the postformation constraints.

\subsubsection{IW-26}

IW-26 is characterized by relatively large grains (Table 1), suggesting either older crystals or conditions favouring recrystallization at higher temperature. The equigranular texture implies no preferred direction of growth (as would be the case for the freezing of a water reservoir) and absence of significant deformation. The horizontal girdles of the c-axes with a localized maximum have several potential explanations: (a) gravity settling of individual snow grains in a narrow vertical crack; (b) deformation of ice in the ice wedge during cyclic contractions; or (c) a combination of these processes. The spherical bubbles indicate that this ice wedge was not formed exclusively by freezing of liquid water as in lake ice (Andersen et al., 1998; Lorrain et al., 2002) or in some ice wedges (St-Jean et al., 2011; French, 2007), supporting a snow-water mixture hypothesis rather than only water infilling for the ice wedge genesis. The total gas content is low in comparison with a dry firn densification process (between one-tenth and one-third of the value of a dry firnification process; Martinerie et al., 1992) implying liquid water contribution to the ice formation. Indeed, in the absence of processes expelling the gases, the gas content can be a proxy for the liquid water contribution to the snow matrix during the time of ice formation.

$\mathrm{CO}_{2}$ mixing ratios in IW-26 are well above the presentday values (Fig. 7, row 2, left and Table 1). This indicates that the ice did not simply capture the atmospheric gas composition. Previous studies on ice in other environments have shown that this is very often the case, mainly because of either the presence of liquid water and/or significant biological activity within the enclosed organic matter fraction (Souchez et al., 1995). Theoretically, the high $\mathrm{CO}_{2}$ solubility in water could raise the $\mathrm{CO}_{2}$ mixing ratio in the dissolved phase up to about $20000 \mathrm{ppmV}$ (at $0^{\circ} \mathrm{C}$ and 1 atmosphere, with limited effect of pressure and impurities). Freezing of a $\mathrm{CO}_{2}$ saturated freshwater reservoir in a closed system could therefore display such high $\mathrm{CO}_{2}$ values. There are however a number of other potential ways to further increase the $\mathrm{CO}_{2}$ mixing ratio in our ice wedge ice such as diffusion-driven gas fractionation at the freezing front, $\mathrm{CO}_{2}$ degassing on calcium carbonate precipitation, thermal trapping or biological respiration. Rejection of impurities at the interface by ice growing in a water reservoir will set up a strong diffusion gradient in the adjacent liquid boundary layer. This could lead to a further increase of the mixing ratio of the least diffusive gas in the solution, as for instance $\mathrm{CO}_{2}$ (Killawee et al., 1998). However, theoretically, this effect cannot increase the $\mathrm{CO}_{2}$ concentration by a factor higher than the ratio of the $\mathrm{CO}_{2}$ diffusion coefficient $\left(\mathrm{DCO}_{2}\right)$ to the air diffusion coefficient (Dair) in water, i.e. by a factor of about 1.6 (using typical values for $\mathrm{DCO}_{2}, \mathrm{DN}_{2}, \mathrm{DO}_{2}$ ). This would increase the $\mathrm{CO}_{2}$ mixing ratio to about $30000 \mathrm{ppmV}$, provided that the freezing process can be assimilated in this case to ice growing in a liquid interface. Killawee et al. (1998) have shown that unidirectional freezing of a supersaturated $\mathrm{CaCO}_{3}$ solution leads to a strong $\mathrm{CO}_{2}$ enrichment of the refrozen water due to the $\mathrm{CO}_{2}$ degassing resulting from the carbonate precipitation. The lack of reaction of our ice wedge sediments to an $\mathrm{HCl}$ "attack" however does not support the existence of significant amounts of $\mathrm{CaCO}_{3}$. Biological respiration could be an active process since bacteria and microbial communities have been identified in permafrost ice and in ice wedges (Gilichinsky et al., 2007; Katayama et al., 2007; Steven et al., 2008). Specific studies on these organisms would enable confirmation of this hypothesis.

The considerations above suggest that the $\mathrm{CO}_{2}$ mixing ratios of IW-26 result from a combination of purely physical processes (solubility) and biological respiration processes. 

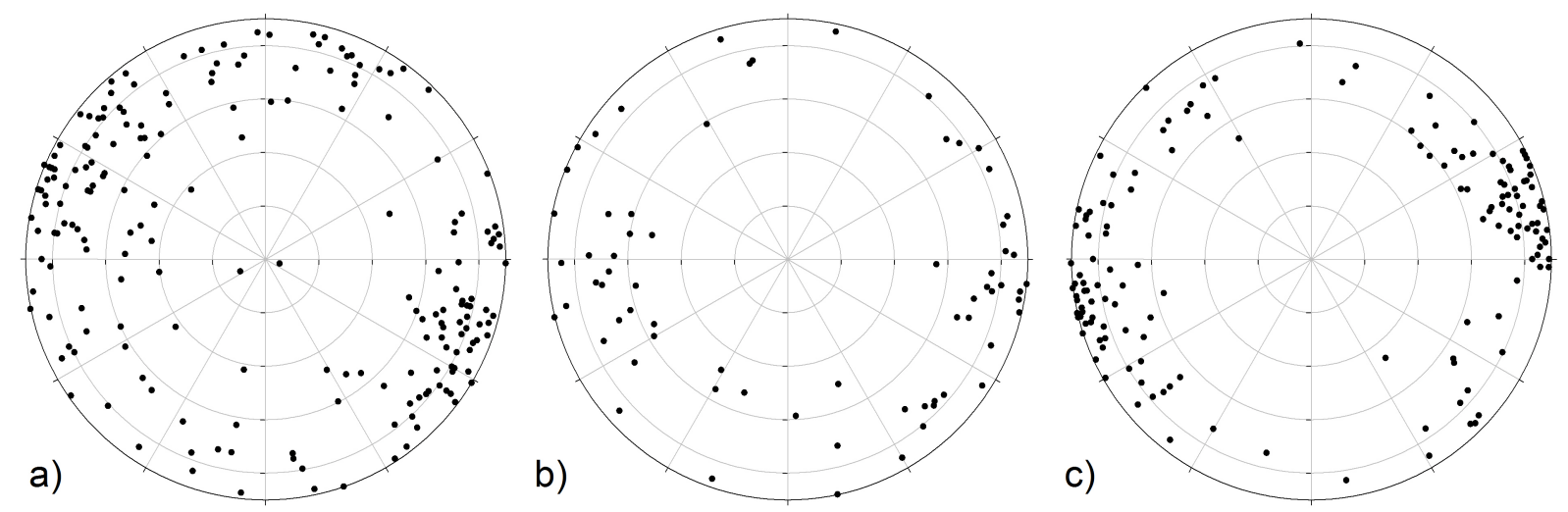

Fig. 6. Schmidt equal-area diagrams for the c-axes of horizontal thin sections. (a) a total of six thin sections from IW-26 ( $n=199)$ showing horizontal girdle with 1 maximum, (b) a total of two thin sections from ISW-28 $(n=70)$ showing horizontal girdle, (c) a total of five thin sections from IW-28 $(n=150)$ showing horizontal girdle with 1 maximum.

Table 1. Summary of results and comparison between IW-26, ISW-28 and IW-28. Values shown are minimum-maximum, mean.

\begin{tabular}{|c|c|c|c|}
\hline & IW-26 & ISW-28 & IW-28 \\
\hline Crystal area range $\left(\mathrm{mm}^{2}\right)$ & $10.18-27.34$ & $4.15-9.62$ & $0.95-4.15$ \\
\hline Crystal shape & equigranular & $\begin{array}{l}\text { granular/rectangular elongated vertically } \\
\text { sediments at grain boundary }\end{array}$ & equigranular \\
\hline c-axes & 1 max in horizontal girdle & horizontal girdle & 1 max in horizontal girdle \\
\hline Bubble size & $\sim 1 \mathrm{~mm}$ & $\sim 1 \mathrm{~mm}$ & $\sim 1 \mathrm{~mm}$ \\
\hline Bubble shape & spherical & spherical & spherical \\
\hline Total gas content* $(\mathrm{mL} \mathrm{kg}-1)$ & 10 to 36,27 (homogeneous) & 11 to 42,25 (heterogeneous) & 27 to 50,45 (homogeneous) \\
\hline $\mathrm{N}_{2}(\%)$ & 77 to 86,82 & 78 to 89,85 & 82 to 89,86 \\
\hline $\mathrm{O}_{2}(\%)$ & 5 to 13,10 & 10 to 21,15 & 10 to 13,12 \\
\hline $\operatorname{Ar}(\%)$ & 1.16 & 1.03 & 0.93 \\
\hline $\mathrm{CO}_{2}(\mathrm{ppmV})$ & 35000 to 110000,62000 & 860 to 7000,3000 & 10000 to 48000,25000 \\
\hline $\mathrm{CH}_{4}(\mathrm{ppmV})$ & 0.5 to $1.6,1$ & 41 to 72,55 & 7 to 10,8 \\
\hline$\delta^{18} \mathrm{O}(\% \circ)$ & -30.6 to $-22.6,-24.9$ & -30.9 to $-28.9,-29.9$ & -31.9 to $-29.4,-31$ \\
\hline$\delta \mathrm{D}(\% \circ)$ & -230 to $-170,-188$ & -246 to $-230,-237$ & -247 to $-4229,-240$ \\
\hline$\delta^{18} \mathrm{O} / \delta \mathrm{D}$ slope $(\% \circ)$ & $6.63\left(r^{2}=0.94\right)$ & $8.03\left(r^{2}=0.98\right)$ & $7.44\left(r^{2}=0.98\right)$ \\
\hline
\end{tabular}

*Meteoric ice values range between 75 and $140 \mathrm{~mL} \mathrm{~kg}^{-1}$; Martinerie et al. (1992)

Isotopic measurements of the ${ }^{13} \mathrm{C}$ of $\mathrm{CO}_{2}$ or of the ${ }^{18} \mathrm{O}$ of the $\mathrm{O}_{2}$ in our samples would further support this assessment (Cardyn et al., 2007; Souchez et al., 2006), but these data are currently not available.

$\mathrm{CH}_{4}$ mixing ratios are rather low (Fig. 7, row 3, left - Table 1) in the range of Pleistocene-present-day atmospheric values, and we therefore assume no significant contribution from a substrate source or bacterial production.

The $\delta^{18} \mathrm{O} / \delta \mathrm{D}$ values in IW-26 are in the range of Late Glacial to Holocene ice wedges (Fig. $6 \mathrm{~b}$ in Wetterich et al., 2011). The slope (6.63) of the linear regression line in the coisotopic diagram of Fig. $3 \mathrm{c}$ is however quite different from the known values of the local meteoric water line in the region (slope of 7.6 at Tiksi station, H. Meyer, unpublished data). Paleoclimatic interpretation of the stable isotopes signature in ice wedges is usually challenged by the possibility that water phase changes during evaporation/sublimation or melting/refreezing may affect the isotopic composition through fractionation, and therefore potentially alter the original paleoclimatic signature of the ice wedge. Refreezing processes will shift the $\delta$ values towards less negative values (e.g. max. $+3 \%$ o for $\delta^{18} \mathrm{O}$ and $+21 \%$ ofor $\delta \mathrm{D}$ in a single refreezing process) and will also decrease the slope of the $\delta^{18} \mathrm{O}-\delta \mathrm{D}$ co-isotopic relation (Souchez and Lorrain, 1991). This is described by the "freezing slope", which is expressed in the more general case of open systems as

$$
S=\frac{\alpha-1}{\beta-1} \times \frac{1000+\delta_{\mathrm{i}} \mathrm{D}}{1000+\delta_{\mathrm{i}}^{18} \mathrm{O}}
$$

where

$$
\begin{aligned}
& \alpha=1.0208 \text { for deuterium } \\
& \beta=1.003 \text { for }{ }^{18} \mathrm{O}
\end{aligned}
$$



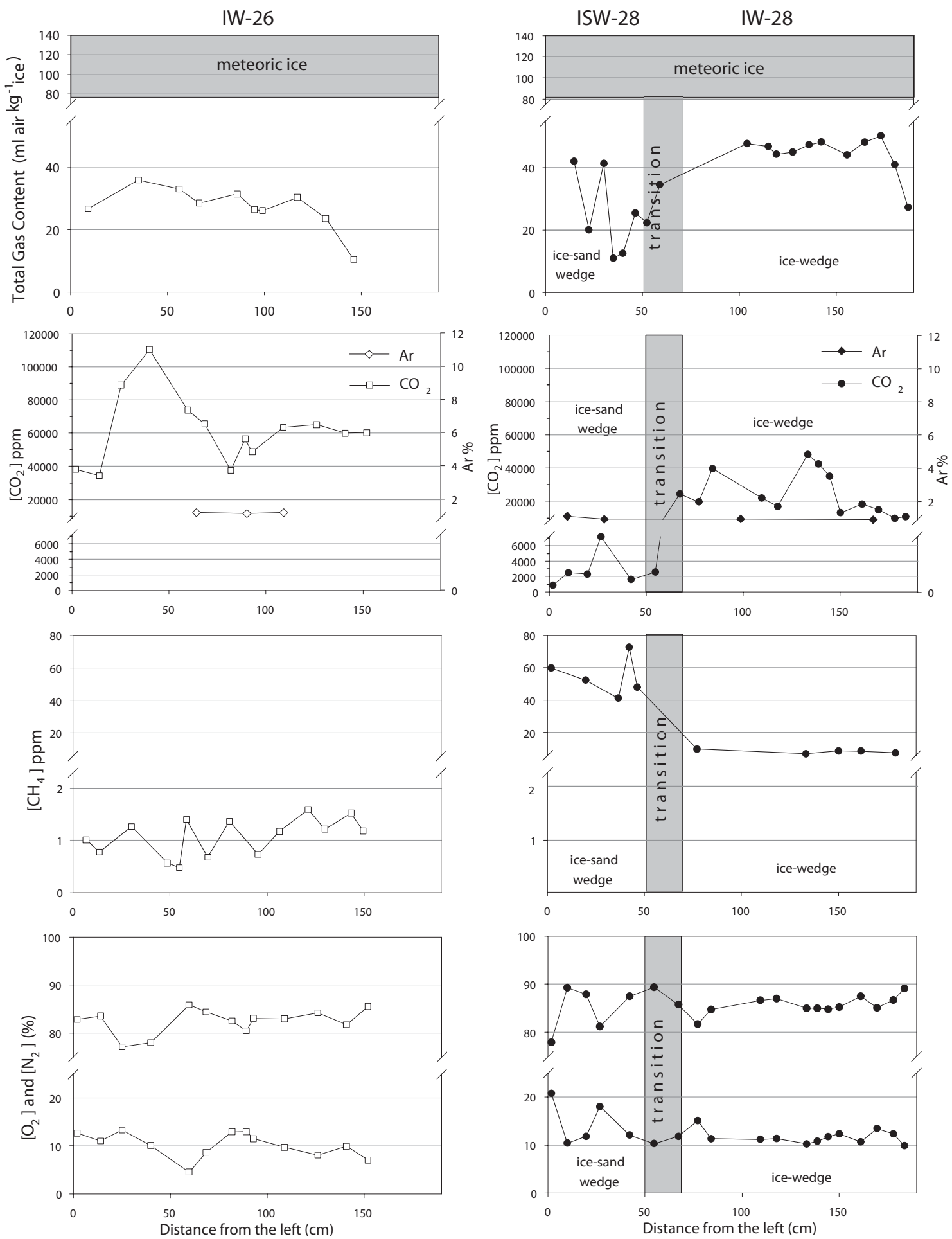

Fig. 7. Gas properties of ice wedges IW-26 (left) and ISW-28/IW-28 (right).

$\delta_{\mathrm{i}}=$ isotopic composition of the initial liquid.

This concept has been used by St-Jean et al. (2011) to associate lower co-isotopic slopes to melting-refreezing processes in Holocene ice wedges. It is however important to underline that a "freezing slope" as such will only develop if the scale of the freezing process (size of the water reservoir) is considerably larger than the resolution of the isotopic sampling. In the case of ice wedges, typical crack-widths are of the order of a few centimeters (Harris et al., 1988), 
and annual "ice veins" are generally observed to be between $1 \mathrm{~mm}$ and $1 \mathrm{~cm}$ in width. It is therefore quite unlikely to develop a "freezing slope" from a several-meter-wide ice wedge, using a stable isotopes data set at a resolution of a few centimeters (about $1 \mathrm{~cm}$ in our case). This is probably also one of the reasons why $\delta^{18} \mathrm{O} / \delta \mathrm{D}$ signatures of ice wedges might have paleoclimatic significance. Small-scale refreezing or evaporation/sublimation processes, if present, could however slightly induce localized small-scale variability towards lower slopes, which might explain the observed lower co-isotopic slope and the lowering of the correlation coefficient $\left(r^{2}=0.94\right)$ observed in the case of IW-26.

To summarize, our IW-26 analyses enable us to conclude that ice-vein formation in this ice wedge results from refreezing of a water-snow mix, with a large proportion of snow, no directional freezing, although a slight influence of the horizontal temperature gradient on the depositional c-axes orientations might exist. The co-isotopic slope is probably affected by small-scale freezing dispersion of the samples. Relatively low gas content and a mixed signature of solubility and respiration processes are also demonstrated for $\mathrm{CO}_{2}$. These properties are consistent with an ice wedge developing under relatively warm and relatively wet Holocene conditions.

\subsubsection{ISW-28}

ISW-28 shows medium grain size suggesting less recrystallization and/or younger age than IW-26 (which is actually precluded by the relative stratigraphical position of the two ice wedges, as discussed before). The alternation of equigranular and rectangular crystals (ribbon layer) elongated parallel to the crack side is the main characteristic of the ice-sand wedge part. This type of structure has, to our best knowledge, never been described in ice wedges and resembles the "stratified facies" found in basal glacier ice (e.g. Tsijiore Nouve, Switzerland) where ice results from film water refreezing on subglacial cavity floors. Although these ice types come from different environments, their formation is likely due to the same process. In our case we assume interface freezing on the cold surface of the frost crack walls of a thin running water film originating from summer melting of the surface lips of the partially open (unfilled) crack (as opposed to a "top-down" or "side-centre" refreezing of an "in situ" bulk water reservoir). Sediments at layer boundaries suggest entrainment with the meltwater from the surface, rejection from the growing ice and, finally, freeze-in during "shut-down" phases of the water supply. The horizontal girdle drawn by the c-axis distribution does not show a localized maximum, but, as mentioned before, the number of samples is relatively low. The observed high small-scale variability of total gas content is probably due to the alternation of layers with bubbles (episodes of wet snow metamorphism) and layers without (ribbon layer formed through water film freezing). $\mathrm{CO}_{2}$ is higher than atmospheric values (solubility effect) but well below the solubility limit of $20000 \mathrm{ppm}$, therefore suggesting an "open system" freezing with gas rejection to the atmosphere. $\mathrm{CH}_{4}$ mixing ratios are much higher than the atmospheric value, suggesting methane production in bubbles or in soil, in close vicinity to the bubbles before their occlusion in the ice vein. Note that the sediments in the ice-sand wedge part are rich in organic matter and provide an adequate substrate for methanogenic bacteria.

Apart from a few values close to atmospheric in ISW-28, the $\mathrm{O}_{2}$ mixing ratio fluctuates around $10 \%$ (Fig. 7, row 4), being only half the atmospheric $\mathrm{O}_{2}$ value. It is hard to tell if this value is the gaseous composition of the local environment (in the crack into the frozen soil) before the bubbles "close-off" or if this value is a result of biogeochemical postocclusion processes.

The $\delta^{18} \mathrm{O}$ and $\delta \mathrm{D}$ values match well with Pleistocene stadial signature in the studied area (Fig. $6 \mathrm{c}$ in Wetterich et al., 2011). The slope in the co-isotopic diagram (8.03) could be indicative of the variability of the autumn-winter snow input to the crack during the integrated period of the ice-sand wedge history. Snow samples in this region do not receive additional secondary moisture (because open water bodies are frozen in winter) and therefore are generally situated close to the GMWL (global meteoric water line) (Meyer et al., 2002a, b) with slopes in the co-isotopic diagram close to 8 .

ISW-28 ice vein properties suggest presence of successive episodes of consolidation of snow-water mixtures alternating with refreezing of a film of running water descending the sides of the open frost crack. The fact that the crack is not always filled with snow might indicate periods favouring debris incorporation either through an increased input of particulate contribution from the surface or because of a thinner snow cover (lower precipitation). It is worth noting that a globally colder-drier period (as suggested by the low precipitation) does not necessarily mean less melting in the period when frost cracks are open, if debris availability allows strong summer albedo effects. The biological activity in ISW-28 is characterized by low to moderate aerobic respiration but high methanogenic activity related to availability of organic matter and lower than atmospheric oxygen levels. These conditions obviously existed during the early stages of IW-28 development (ISW-28).

\subsubsection{IW-28}

IW-28 shows the smallest grain size. This is potentially the combined result of a lower Arrhenius growth rate at lower temperature and less liquid water availability (which would otherwise enhance crystal growth rate). Clearly these factors outweigh the time factor (older ice) in the recrystallization process. The equigranular ice does not show preferred direction of freezing, and the horizontal girdle shows one localized maximum sub-perpendicular to the foliation, as for the IW-26. As in IW-26 also, the spherical bubbles indicate no directional freezing and favour a consolidation process of a snow-water mixture for the origin of the ice veins. However, 
the highest total gas content, with values reaching about $50 \%$ of those observed in dry firnification, suggests less liquid water contribution than in IW-26. This might be linked to the small-scale hydrodynamical processes at play as the meltwater percolates into the snow infilling. Colder temperatures in the surface permafrost from the previous winter would favour rapid freezing in the surface layer and limit water percolation further down-crack. Detailed vertical gas content profiles would certainly be useful in documenting these processes further.

$\mathrm{CO}_{2}$ mixing ratios contrast with those observed in the ISW-28 section and are closer to those observed in ice wedge IW-26, showing the potential combination of pure physical solubility processes with biological respiration, although the latter is less developed than in IW-26. $\mathrm{CH}_{4}$ mixing ratio, largely higher than the atmospheric values, is also intermediate between those of IW-26 and ISW-28. $\delta^{18} \mathrm{O}$ and $\delta \mathrm{D}$ values are similarly low as compared to ISW-28 and might suggest a slightly colder period for IW-28.

IW-28 would therefore have formed from a water-snow mix, at a lower temperature than IW-26, with a large proportion of snow, no directional freezing and less sediment input than in ISW-28. The latter results in moderate $\mathrm{CH}_{4}$ mixing ratios, although these are higher than those measured in the Holocene ice wedge IW-26. Fabrics are still dominated by horizontal c-axes including a single maximum roughly perpendicular to the crack sides, suggesting gravity settling control or contraction deformation effects rather than recrystallization growth, given the isotropy of the bubbles and crystal shapes.

Our interpretation of the ice wedge filling process and ice vein formation contrasts with St-Jean et al. (2011) who suggest that the Holocene ice wedges result from the freezing of liquid water and that the Pleistocene ice wedges result rather from snow densification and/or hoarfrost accretion. Our study suggests a variable water-snow mix as a source of the ice with higher water contribution during the Holocene period. Concurrent with data from Lacelle et al. (2011) and St-Jean et al. (2011), however, our $\delta\left(\mathrm{N}_{2} / \mathrm{Ar}\right)$ and $\delta\left(\mathrm{O}_{2} / \mathrm{Ar}\right)$ results (Fig. 8) indicate an increasing influence of biological processes with the increasing amount of water in the water-snow mix. Interestingly, the proximity of the debris source could result in a larger proportion of meltwater as compared to the snow matrix, and enhanced methanogenesis even though the climate is colder. The latter is supported by a study of Meyer et al. (2010a) in northern Alaska, where an ice wedge component formed during the colder Younger Dryas displays higher methane concentrations as compared to an ice wedge section formed during the warmer Allerød. Clearly, environmental, physical and biological controls need to be considered when discussing ice wedge properties.

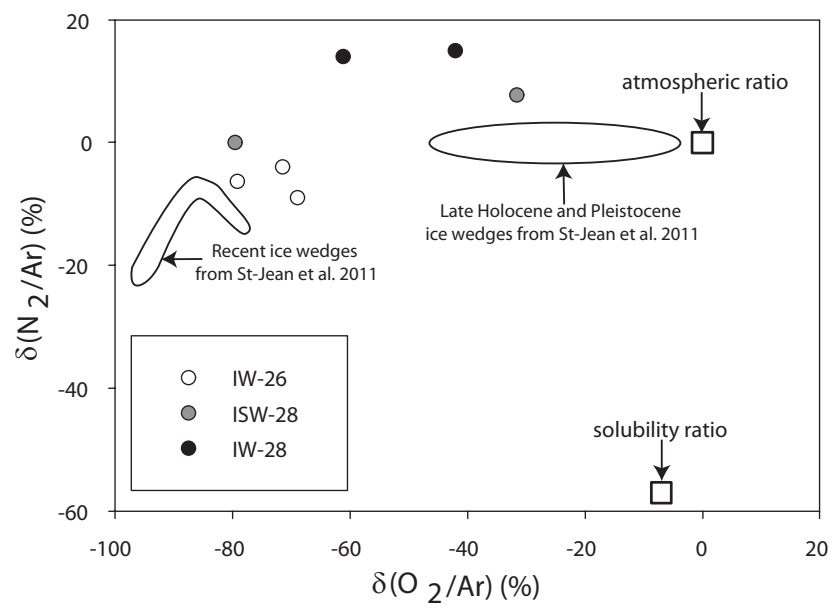

Fig. 8. $\delta\left(\mathrm{N}_{2} / \mathrm{Ar}\right)$ and $\delta\left(\mathrm{O}_{2} / \mathrm{Ar}\right)$ of ice wedges IW-26, ISW-28 and IW-28 using the following equation: $\delta\left(\mathrm{N}_{2} / \mathrm{Ar}\right)=\left(\frac{R\left(\mathrm{~N}_{2} / \mathrm{Ar}\right)_{\mathrm{sa}}}{R\left(\mathrm{~N}_{2} / \mathrm{Ar}\right)_{\mathrm{st}}}-1\right)$ where "sa" refers to the sample and "st" to the standard value (standards used are 22.43 and 83.60 for $\mathrm{O}_{2} / \mathrm{Ar}$ and $\mathrm{N}_{2} / \mathrm{Ar}$, respectively). An equivalent formula is used for determining $\delta\left(\mathrm{O}_{2} / \mathrm{Ar}\right)$.

\subsection{Links to the regional paleoclimatic interpretation}

Results from texture, fabric and gas analyses allow to differentiate between three facies within the two studied ice wedges (IW-26, ISW-28 and IW-28), which can also be discussed in terms of the regional paleoclimatic interpretation from available stable isotope data.

The IW-26 displays least negative $\delta \mathrm{D}$ and $\delta^{18} \mathrm{O}$ values, largest crystal sizes, lowest total gas contents and is embedded in the ice complex structure of Pleistocene age. However, its isotopic composition is coherent with Holocene age ice wedges $\left(\delta^{18} \mathrm{O}\right.$ around -24 to $-25 \%$; Meyer et al., 2000, 2002a, b, 2010b; Dereviagin et al., 2002; Schirrmeister et al., 2002; Popp et al., 2006). A period of mild temperatures would also increase the rate of biological respiration processes and the availability of organic matter.

The lower isotopic composition of IW-28 suggests a Pleistocene origin (compare Fig. $6 \mathrm{~b}$ of the recent regional overview in Wetterich et al. (2011). The situation is however certainly more complex for the ISW-28/IW-28 case as suggested by the strong contrast in their $d$ values, while showing in both cases low internal variability (mean $d=1.4 \%$ o for ISW-28 and mean $d=7.5 \%$ for IW-28) for similar $\delta \mathrm{D}$ ranges (Fig. 4). Also worth noting is the sharp monotonic transition in $d$ values at the interface between ISW-28 and IW-28.

There are a number of ways to explain low $d$ values in precipitation (and in the ice that evolves from it) that were derived from water cycle processes or in-situ post-deposition. Extensive work has been done dealing with the concept and use of $d$ in co-isotopic studies, especially in the field of deep ice-core interpretation and the relation to temperature changes at precipitation sites and oceanic sources (Craig, 
1961; Dansgaard, 1964; Merlivat and Jouzel, 1979; Yurtsever and Gat, 1981; Jouzel et al., 1982, 2005a, b; Jouzel and Merlivat, 1984; Johnsen et al., 1989; Masson-Delmotte et al., 2005; Stenni et al., 2001, 2004; Vimeux et al., 2002, 1999). It is commonly assumed that, although humidity and wind speed at the source also play a role, in most cases, the $\delta^{18} \mathrm{O}_{\text {ice }}$ and $\delta \mathrm{D}_{\text {ice }}$ primarily depend on the temperature at the site $\left(T_{\text {site }}\right)$ and to a lesser extent on the temperature at the source $\left(T_{\text {source }}\right)$. The reverse is true for the $d$ in the ice. The latter is indeed mainly driven by kinetic isotopic effects during evaporation at the oceanic source, and these will be enhanced for higher temperatures and lower relative humidity, increasing the $d$ value (Masson-Delmotte et al., 2005; Merlivat and Jouzel, 1979). It should however be kept in mind that, at equivalent source temperatures, lower wind speeds would also increase the relative humidity at the source and therefore decrease the $d$ excess (Souchez and Lorrain, 1991). Indeed, assuming that the sea surface is at saturation pressure, then increasing wind speed would increase the turbulent flux and hence moisture transport through the boundary layer. As shown in the deep ice core records from Greenland, large topographic and atmospheric circulation changes during the last glacial period (the presence of ice sheets of variable size, larger but fluctuating extension of the sea ice) are responsible for an antiphase relationship between $\delta$ values $\left(T_{\text {site }}\right)$ and $d$ values $\left(T_{\text {source }}\right)$. Indeed, during mild events, when Greenland was warmer (less negative $\delta$ 's) and sea ice less extent, the moisture source was closer (colder) and therefore the $d$ lower than during more severe phases. This results in the samples from these milder periods (less negative $\delta \mathrm{D}$ and $\delta^{18} \mathrm{O}$ ) aligning, in a $\delta \mathrm{D}-\delta^{18} \mathrm{O}$ diagram, on a line with slope close to 8 , but with the $d$ intercept at $+4 \%$ instead of $+8 \%$ o (e.g. Fig. 7 in Johnsen et al., 1989).

Ice cores from central areas of ice sheets are however well constrained in their chronology, which makes them an ideal tool to discuss paleodata in terms of changes in largescale circulation patterns. This is less true for ice wedge data for which limited extension and regional environmental settings (e.g; coastal location, spatial gradients in this study) are likely to affect the proxies. Today, the main source of the winter precipitation in our study area (west of $\sim 140^{\circ} \mathrm{E}$ ) is probably located in the North Atlantic (Kuznetsova, 1998; Rinke et al., 1999). However, as discussed by Meyer et al. (2002b) and Wetterich et al. (2011), Pleistocene moisture sources for the same area are less straightforward to locate. Two hypotheses were discussed (Table 2): (1) refers to a permanent Atlantic source, with a latitudinal variation similar to that suggested by Johnsen et al. (1989), as described above for Greenland. In that scenario, a contrasting $d$ signature would represent a temporal shift (within the Pleistocene, e.g. interstadial/stadial) from a milder (Table 2, column 2) glacial period (higher $T_{\text {site }}$ ) with a higher relative humidity (i.e. lower $T_{\text {source }}$ and/or lower winds, and therefore lower $d$ values in ISW-28) to a colder glacial period (lower $T_{\text {site }}$ ) with a lower relative humidity (i.e. higher $T_{\text {source, }}$ and/or
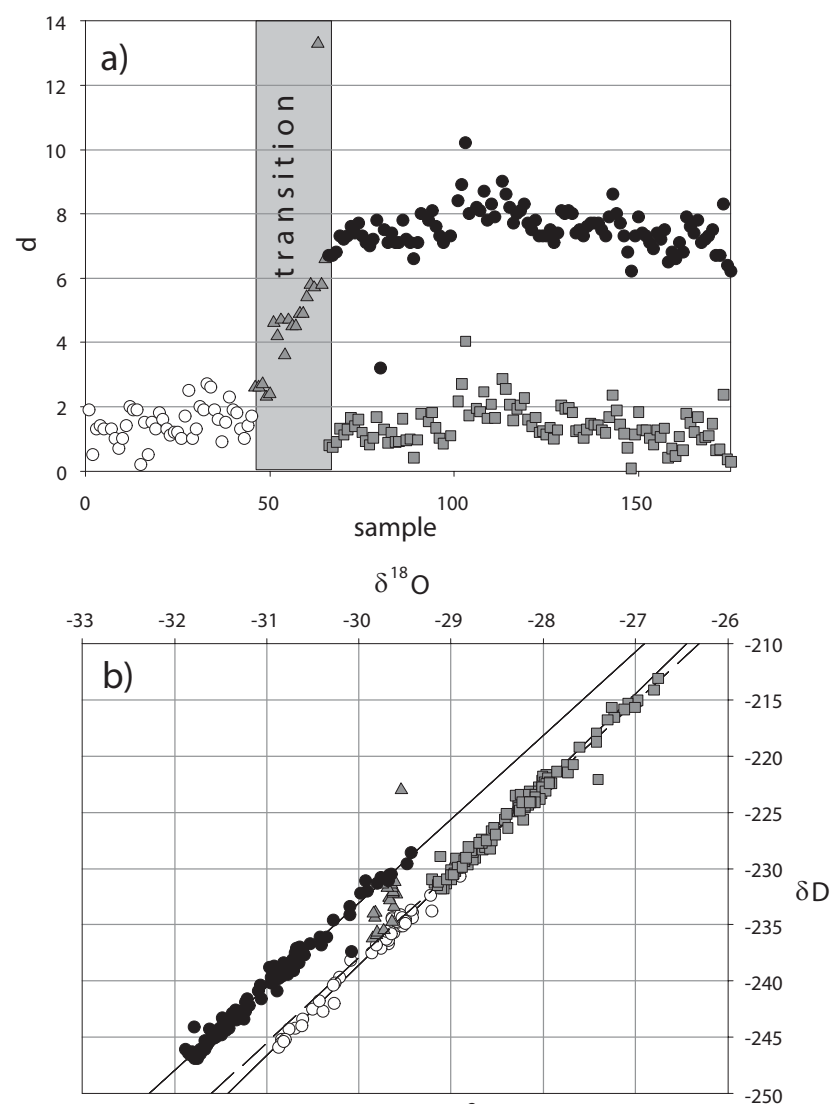

- IW-28 (S=7.44; $d$ intercept $=-9.89 ; r^{2}=0.98$

$\triangle \quad$ Transition zone ISW-28/IW-28

- ISW-28 (S=8.03; $d$ intercept $\left.=2.22 ; r^{2}=0.98\right)$

- Transformed samples $\left(S=7.56 ; d\right.$ intercept $\left.=-10.88 ; r^{2}=0.98\right)$

Fig. 9. $d$ (a) and co-isotopic plots (b) of observed data for ISW28 (open circles) and IW-28 (black dots) compared to a simulation (grey squares) on the effect of hypothetical equilibrium refreezing of $10 \%$ of melted fraction in IW-28 sample, using Eq. (1). The refrozen theoretical IW-28 samples reproduce the $d$ of the ISW-28 samples and lie on the same co-isotopic line. They are however clearly offset towards less negative $\delta$ values.

higher winds, and therefore higher $d$ value in IW-28). The amount of precipitation, however, should be lower during cold stadial periods and higher during interstadials (as for the difference between glacials and interglacials in deep ice cores and in permafrost). Alternatively, (2) the combination of the full development of the Eurasian ice sheet (the easternmost extent of which reached the western part of Taymyr Peninsula) and of an extended sea ice cover in the Barents and Kara seas and the North Atlantic (stadial, Table 2, column 5) might have considerably reduced (deflected or even blocked, Meyer et al., 2002a) the penetration of Atlantic air masses to the Laptev Sea region. In that case, a stronger influence of the North Pacific winter moisture source, with low $d$ values and low precipitation (e.g. Clark and Fritz, 1997), could have existed. During interstadials (Table 2, column 4), 
Table 2. Comparison of relative values of $\delta, d$ and precipitation amount for the two sections of ice wedge ISW-28/IW-28 with expected values for the two atmospheric moisture source hypotheses discussed in the text.

\begin{tabular}{|c|c|c|c|c|c|c|}
\hline (1) & (2) & (3) & (4) & $(5)$ & (6) & (7) \\
\hline \multirow[t]{2}{*}{ variables } & \multicolumn{2}{|c|}{ Hyp. 1: Atlantic source } & \multicolumn{2}{|c|}{ Hyp. 2: Atlantic vs. North Pacific } & \multirow[t]{2}{*}{ ISW-28 } & \multirow[t]{2}{*}{ IW-28 } \\
\hline & $\begin{array}{l}\text { low sea ice } \\
\text { Interstadial }\end{array}$ & $\begin{array}{c}\text { high sea ice } \\
\text { Stadial }\end{array}$ & Interstadial & Stadial & & \\
\hline$\delta$-values $^{\mathrm{a}}$ & high & low & high & low & low & lower \\
\hline$d$ values $^{\mathrm{b}}$ & low & high & high & low & low & high \\
\hline Precipitation $^{\mathrm{c}}$ & high & low & high & low & low & high \\
\hline
\end{tabular}

${ }^{\text {a }}$ primarily influenced by the temperature at the site location;

${ }^{b}$ primarily influenced by the temperature at the moisture source location;

distance controlled.

on the contrary, a distinct North Atlantic source could have been re-established, with potentially higher $d$ values (more "southerly" sources) and higher precipitation (Lacelle et al., 2011). We will discuss below these two alternatives, in light of the other ice properties. Note however that available data on large-scale changes in circulation patterns across stadialinterstadial transitions during the Pleistocene are poorly documented and that the occurrence of this specific North Pacific moisture low $d$ isotopic signature east of our study site is still somewhat controversial in ground ice (Schwamborn et al., 2006).

Climatic seasonal variations (temperature, precipitation, etc.) are also able to disturb $d$ (Johnsen et al., 1989; Meyer et al., 2002b), but ice wedges are known to be built from the winter snow precipitation mainly and the spring meltwater derived from it. Post-depositional "in situ" phase changes could also be responsible for lowering the $d$ values of the samples (Meyer et al., 2002b). Isotopic fractionation during ice wedge consolidation was discounted by Michel (1982) based upon the argument that freezing is generally too fast to allow for it. However, conditions might be different for the formation of the "ribbon facies" in the ice-sand wedge for example. Figure 9 shows the effect of equilibrium fractionation during hypothetical $10 \%$ refreezing (grey squares) of water resulting from the melting of each of the samples from IW-28 (black dots). The mean isotopic composition of the $10 \%$ refrozen fraction was computed using the formulation in Souchez and Lorrain (1991) as in Eq. (2), with a frozen fraction $(K)=0.10$.

$\bar{\delta}_{s}=10 \times\left(1000+\delta_{0}\right) \times\left[(1.1-K)^{\alpha}-(1-K)^{\alpha}\right]-1000$

where

$\bar{\delta}_{\mathrm{s}}=\delta$ value of refrozen samples

$\delta_{0}=\delta$ value of water (melted IW-28 ice sample, no fractionation on melting; Moser and Stichler, 1980; Souchez and Lorrain, 1991)

$K=$ frozen fraction $\alpha=$ fractionation coefficient (1.0208 for deuterium and 1.003 for ${ }^{18} \mathrm{O}$ ).

The refrozen IW-28 samples indeed reproduce the $d$ of the ISW-28 samples and lie on the same co-isotopic line. They are however clearly offset towards less negative $\delta$ values, and more negative $\delta$ values than observed in IW-28 would be required to explain the observed ISW-28 $\delta$ range. This is not precluded, given the existence of some more negative values from the Sartan period reported by e.g. Wetterich et al. (2011, Fig. 6) in other ice wedges of the area. Experimental sublimation/evaporation processes of a snow pack have also been shown to shift the remaining reservoir towards less negative isotopic values with a slope that is less than 8 (Souchez and Lorrain, 1991 and references within). However, although they could reproduce the observed $d$ values in ISW-28, both of these post-depositional processes would need to be occurring at a rigorous equivalent rate (e.g. $10 \%$ refreezing, fixed evaporation percentage) for all samples to plot on a coisotopic line as well defined as the one observed for the ISW28 samples, with a slope close to 8 . In fact, the very good alignment of all the ISW-28 samples on a line with a slope of $8.03\left(r^{2}=0.98\right.$, with a fairly low range of the $\delta$ values $)$ is an argument to favour a "classical" Rayleigh-type "source to sink" fractionation history.

Since post-depositional isotopic changes are not satisfactorily explaining the contrasting deuterium excess signature between ISW-28 and IW-28, we investigate here below if the other ice properties bring some support to one of the two poorly constrained circulation patterns proposed by Meyer et al. (2002b) and Wetterich et al. (2011).

The answer is not straightforward. Indeed, ISW-28 has very low $d$ values (Table 2, column 6 and Fig. 4) that would either correspond to an interstadial period in hypothesis 1 (Atlantic source, little sea ice cover - Table 2, column 2) or to a stadial in hypothesis 2 (North Pacific source - Table 2, column 5). The latter option is coherent with the deduced lower relative precipitation amounts from the observation of the ice-vein properties at ISW-28. However, in that case, the "insitu" temperature should be lower at ISW-28 than at IW-28 
(which would then be typical of re-establishment of an Atlantic source with higher $d$ values and higher precipitation). Alternatively, higher $T_{\text {site }}$ for ISW-28 fit to an interstadial in hypothesis 1 (change in position of Atlantic source), but then higher precipitation amounts should be expected (Table 2, column 2). Note however that the $\delta$ contrast is low between ISW-28 and IW-28, and that it should also be strong if hypothesis 1 was valid, with much higher values for ISW-28, provided that the mechanism is similar to the one presented for the Greenland Ice Sheet "stadial-interstadial" alternation by Johnsen et al., 1989. The latter assumption is hypothetical. Indeed, precipitation and temperature regimes on the downwind side of major ice sheets might have been quite different to those existing in its centre parts (e.g. foehn effects, which would locally increase temperatures and lower precipitations). One could also argue that the "switch" from North Pacific to Atlantic sources in hypothesis 2 could also be primarily linked to changes in the Greenland and Eurasian ice sheet geometries, which might in turn not be directly linked to contrasted global temperature regimes but to other mechanisms such as ice-ocean interactions.

In the ISW-28 ice-sand wedge, the dominance of debris input over snow filling suggests a period of limited precipitation in accordance with the North Pacific winter moisture source with a low $d$ value. However, the thin sections suggest the presence of meltwater and of melting-refreezing processes in an open-system, sandwiched with refrozen snow layers of limited extension (also supported by the total gas content measurements). Intuitively, these would be preferably associated with warmer periods, but they could also simply result from albedo effects in this debris-rich environment.

\section{Conclusions}

Detailed crystallographic, gas content and composition, and water isotope analyses of the IW-26 and IW-28 ice wedges allowed us to shed more light on the processes involved in ice wedge growth. Ice wedge IW-26 developed in a mild Holocene environment. Higher temperatures and higher meltwater infiltration resulted in enhanced recrystallization, larger crystal sizes, lower total gas content and favourable conditions for biological respiration, inducing relatively high $\mathrm{CO}_{2}$ levels. Ice wedge ISW-28/IW-28 developed in a relatively mild Pleistocene environment, during which a large change in atmospheric sources occurred, as documented by a sharp monotonous transition in deuterium excess from stable values at ca. $1.4 \%$ in ISW-28 (early growth) to stable values at ca. $7.5 \%$ in IW-28, which cannot be explained through post-depositional processes. This transition occurred without significant changes in the site temperature as indicated by constantly low $\delta^{18} \mathrm{O}$ and $\delta \mathrm{D}$ values. It is however difficult to select potential mechanisms behind the changes in atmospheric sources. The transition is however concurrent with major changes in the ice wedge morphology. The ice- sand wedge ISW-28 properties show a smaller contribution of refrozen "snow-water mix" in the ice veins, with regular episodes of film water open-system refreezing on the crack walls, associated with important losses of total gas content and abundance of surface-derived debris inclusions forming the "ribbon facies". This heterogeneous medium, rich in organic matter, might have favoured the anaerobic microenvironmental conditions necessary to explain the maximum $\mathrm{CH}_{4}$ levels in that unit. Ice vein texture in IW-28 resembles more the refrozen "snow-water mix" of IW-26, but with smaller crystal sizes and larger total gas content, as would be expected from colder conditions.

The changes in $d$ between ISW-28 and IW-28 are most likely linked with changes in the moisture source region from Atlantic to Pacific or changes within an Atlantic source region. The combined observed low $d$ values and limited snow contribution to the ice vein matrix, suggesting low precipitation, in ISW-28 are consistent with a North Pacific atmospheric source for the local precipitation at the time of ISW28 formation. The length and persistence of this low $d$ event is however unknown since it has not been observed at any other ice wedge study site west of $130^{\circ} \mathrm{E}$. The significant contrast in ice vein metamorphic processes between ISW28 and IW-28, suggesting a larger contribution of meltingrefreezing processes in the former, could result from slightly milder conditions at ISW-28. However, the close proximity of the soil-sediment source has certainly fostered melting through albedo feedbacks.

Finally, comparing our methane mixing ratios in IW-26 and IW-28 reveals that substrate availability is as important as the temperature regime in controlling production rates in the permafrost environment.

Acknowledgements. We thank all participants of the RussianGerman expedition "Lena Anabar 2003". Sampling and analytical work in the AWI Potsdam laboratories was supported by Antje Eulenburg, Eileen Nebel, Ute Bastian and Lutz Schönicke. This study is part of the Russian-German cooperative scientific project "System Laptev Sea".

Edited by: H. Eicken

\section{References}

Andersen, D. T., McKay, C. P., and Wharton Jr., R. A.: Dissolved gases in perennially ice-covered lakes of the McMurdo Dry Valleys, Antarctica, Antarct. Sci., 10, 124-33, 1998.

Barnola, J. M., Raynaud, D., Neftel, A., and Oeschger, H.: Comparison of $\mathrm{CO}_{2}$ measurements by two laboratories on air from bubbles in polar ice, Nature, 303, 410-413, 1983.

Berg, T. E. and Black, R. F.: Preliminary measurements of growth of nonsorted polygons, Victoria Land, Antarctica, in: Antarctic Soils and Soil-Forming Processes, American Geophysical Union Antarctic Research Series, (1418), 61-108, 1966. 
Black, R. F.: Features indicative of permafrost, Annual Reviews Inc. Provided by the NASA Astrophysics Data System, 75-94, 1976.

Blunier, T., Chappellaz, J. A., Schwander, J., Barnola, J.-M., Desperts, T., Stauffer, B., and Raynaud, D.: Atmospheric methane record from a Greenland ice core over the last 1000 years, Geophys. Res. Lett., 20, 2219-2222, 1993.

Bobrov, A. A., Muller, S., Chizhikova, N. A., Schirrmeister, L., and Andreev, A. A.: Testate amoebae in late quaternary sediments of the Cape Mamontov Klyk (Yakutia), Biol. Bull., 36, 363-372, 2009.

Cardyn, R., Clark, I. D., Lacelle, D., Lauriol, B., Zdanowicz, C., and Calmels, F.: Molar gas ratios of air entrapped in ice: A new tool to determine the origin of relict massive ground ice bodies in permafrost, Quaternary Res., 68, 239-248, 2007.

Clark, I. and Fritz, P.: Environmental isotopes in hydrogeology, CRC Press (Lewis Publishers), 1997.

Craig, H.: Isotopic variations in meteoric waters, Science, 133, 1702-1703, 1961.

Dansgaard, W.: Stable isotopes in precipitation, Tellus, 16, 436468, 1964

Dereviagin, A. Y., Meyer, H., Chizhov, A. B., Hubberten, H.-W., and Simonov, E. F.: New data on the isotopic composition and evolution of modern ice wedges in the Laptev Sea region, Polarforschung, 70, 27-35, 2002.

French, H. M.: The Periglacial Environment, 3 Edn., Wiley, 2007.

Gilichinsky, D. A., Nolte, E., Basilyan, A. E., Beer, J., Blinov, A. V., Lazarev, V. E., Kholodov, A. L., Meyer, H., Nikolskiy, P. A., Schirrmeister, L., and Tumskoy, V. E.: Dating of syngenetic ice wedges in permafrost with $36 \mathrm{Cl}$, Quaternary Sci. Rev., 26, 15471556, doi:10.1016/j.quascirev.2007.04.004, 2007.

Harris, S. A., French, H. M., Heginbottom, J. A., Johnston, G. H., Ladanyi, B., Sego, D. C., and van Everdingen, R. O.: Glossary of permafrost and related ground-ice terms, Ottawa: National Research Council of Canada, Technical Memorandum 142, 156 p., 1988.

Jacka, T. H.: Laboratory studies on relationships between ice crystal size and flow rate, Cold Reg. Sci. Technol., 10, 31-42, 1984.

Johnsen, S. J., Dansgaard, W., and White, J. W. C.: The origin of Arctic precipitation under present and glacial conditions, Tellus, 41B, 452-468, 1989.

Jouzel, J. and Merlivat, L.: Deuterium and oxygen 18 in precipitation: modeling of the isotopic effects during snow formation, $\mathrm{J}$. Geophys. Res., 89, 11749-11757, 1984.

Jouzel, J., Merlivat, L., and Lorius, C.: Deuterium excess in an East Antarctic ice core suggests higher relative humidity at the oceanic surface during the last glacial maximum, Nature, 299, 688-691, 1982.

Jouzel, J., Masson-Delmotte, V., Stiévenard, M., Landais, A., Vimeux, F., Johnsen, S. J., Sveinbjornsdottir, A. E., and White, J. W. C.: Rapid deuterium-excess changes in Greenland ice cores?: a link between the ocean and the atmosphere, C. R. Géoscience, 337, 957-969, 2005a.

Jouzel, J., Stiévenard, M., Johnsen, S. J., Landais, A., MassonDelmotte, V., Sveinbjornsdottir, A., Vimeux, F., von Grafenstein, U., and White, J. W. C.: The GRIP deuterium-excess record, Quaternary Sci. Rev., 26, 1-17, 2005b.

Katayama, T., Tanaka, M., Moriizumi, J., Nakamura, T., Brouchkov, A., Douglas, T. A., Fukuda, M., Tomita, F., and Asano, K.: Phylogenetic analysis of bacteria preserved in a permafrost ice wedge for 25,000 years, Appl. Environ. Microbiol., 73, 2360-2363, 2007.

Killawee, J. A., Fairchild, I. J., Tison, J.-L., Janssens, L., and Lorrain, R.: Segregation of solutes and gases in experimental freezing of dilute solutions: Implications for natural glacial systems, Geochem. Cosmochim. Ac., 62, 3637-3655, 1998.

Knight, P. G.: Glaciers, Stanley Thornes Ltd., 1999.

Kuznetsova, L. P.: Atmospheric moisture content and transfer over the territory of the former USSR, in: Second International Workshop on Energy and Water Cycle in GAMESiberia, 1997, edited by: Ohata, T. and Hiyama, T., Research Report of IHAS, Institute for Hydrospheric-Atmospheric Sciences, Nagoya University, Nagoya, Japan, 145-151, 1998.

Lacelle, D., Radtke, K., Clark, I. D., Fisher, D., Lauriol, B., Utting, N., and Whyte, L. G.: Geomicrobiology and occluded $\mathrm{O}_{2}-\mathrm{CO}_{2}-$ Ar gas analyses provide evidence of microbial respiration in ancient terrestrial ground ice, Earth Planet. Sc. Lett., 306, 46-54, doi:10.1016/j.epsl.2011.03.023, 2011.

Lachenbruch, A. H.: Mechanics of thermal contraction cracks and ice wedge polygons in permafrost, Geol. S. Am. S., 70, 1-69, 1962.

Langway, C. C. J.: Ice fabrics and the universal stage, SIPRE Technical Report, 62, 1958.

Lauriol, B., Duchesne, C., and Clark, I. D.: Systématique du remplissage en Eau des Fentes de Gel: les Résultats d'une étude Oxygène-18 et Deutérium, Permafrost Periglac., 6, 47-55, 1995.

Lorrain, R., Sleewaegen, S., Fitzsimons, S., and Stievenard, M.: Ice formation in an Antarctic glacier-dammed lake and implications for glacier lake interactions, Arct. Antarct. Alp. Res., 34, 150$158,2002$.

Mackay, J. R.: Ice-Wedge Cracks, Garry Island, Northwest Territories, Can. J. Earth Sci., 11, 1366-1383, doi:10.1139/e74-133, 1974.

Martinerie, P., Raynaud, D., Etheridge, D. M., Barnola, J. M., and Mazaudier, D.: Physical and climatic parameters which influence the air content in polar ice, Earth Planet. Sci. Lett., 112, 1-13, 1992.

Martinerie, P., Lipenkov, V. Y., Raynaud, D., Chappellaz, J., Barkov, N. I., and Lorius, C.: Air content paleo record in the Vostok ice core (Antarctica): A mixed record of climatic and glaciological parameters, J. Geophys. Res., 99, 10565-10576, 1994.

Masson-Delmotte, V., Jouzel, J., Landais, A., Stievenard, M., Johnsen, S. J., White, J. W. C., Werner, M., Sveinbjornsdottir, A., and Fuhrer, K.: GRIP Deuterium Excess Reveals Rapid and Orbital-Scale Changes in Greenland Moisture Origin, Science, 309, 118-121, 2005.

Merlivat, L. and Jouzel, J.: Global climatic interpretation of the deuterium-oxygen 18 relationship for precipitation, J. Geophys. Res., 84, 5029-5033, 1979.

Meyer, H., Schönicke, L., Wand, U., Hubberten, H.-W., and Friedrichsen, H.: Isotope studies of hydrogen and oxygen in ground ice experiences with the equilibration technique, Isot. Environ. Healt. S., 36, 133-149, 2000.

Meyer, H., Dereviagin, A., Siegert, C., Schirrmeister, L., and Hubberten, H.-W.: Palaeoclimate Reconstruction on Big Lyakhovsky Island, North Siberia - Hydrogen and Oxygen Isotopes in Ice Wedges, Permafrost Periglac., 13, 91-105, 2002a.

Meyer, H., Dereviagin, A. Y., Siegert, C., and Hubberten, H.-W.: Paleoclimate studies on Bykovsky Peninsula, North Siberia - hy- 
drogen and oxygen isotopes in ground ice, Polarforschung, 70, 37-51, 2002b.

Meyer, H., Schirrmeister, L., Andreev, A., Wagner, D., Hubberten, H.-W., Yoshikawa, K., Bobrov, A., Wetterich, S., Opel, T., Kandiano, E., and Brown, J.: Lateglacial and Holocene isotopic and environmental history of northern coastal Alaska - Results from a buried ice-wedge system at Barrow, Quaternary Sci. Rev., 29, 3720-3735, doi:10.1016/j.quascirev.2010.08.005, 2010a.

Meyer, H., Schirrmeister, L., Yoshikawa, K., Opel, T., Wetterich, S., Hubberten, H.-W., and Brown, J.: Permafrost evidence for severe winter cooling during the Younger Dryas in northern Alaska, Geophys. Res. Lett., 37, L03501, doi:10.1029/2009GL041013, 2010b.

Michel, F. A.: Isotope investigations of permafrost waters in northern Canada, University of Waterloo, Ontario, Canada, Dept. of Earth Sciences, 1982.

Moser, H. and Stichler, W.: Environmental isotopes in ice and snow, in: Handbook of Environmental Isotope Geochemistry, the terrestrial environment, 1A, edited by: Fritz, P. and Fontes, J., 141178, Elsevier, Amsterdam, 1980.

Müller, S., Bobrov, A. A., Schirrmeister, L., Andreev, A. A., and Tarasov, P. E.: Testate amoebae record from the Laptev Sea coast and its implication for the reconstruction of Late Pleistocene and Holocene environments in the Arctic Siberia, Palaeogeogr. Palaeocl., 271, 301-315, 2009.

Opel, T., Dereviagin, A. Y., Meyer, H., Schirrmeister, L., and Wetterich, S.: Palaeoclimatic information from stable water isotopes of Holocene ice wedges on the Dmitrii Laptev Strait, northeast Siberia, Russia, Permafrost Periglac. Process., 22, 84-100, doi:10.1002/ppp.667, 2011.

Paterson, W. S. B.: The physics of glaciers, third edition, Butterworth-Heinemann, Oxford, 1994.

Pickering, F. B.: The basis of Quantificative Metallography., Metals and Metallurgy Trust, 1976.

Popp, S., Diekmann, B., Meyer, H., Siegert, C., Syromyatnikov, I., and Hubberten, H.-W.: Palaeoclimate Signals as Inferred from Stable-isotope Composition of Ground Ice in the Verkhoyansk Foreland, Central Yakutia, Permafrost Periglac., 17, 119-132, 2006.

Raffi, R., Stenni, B., Flora, O., Polesello, S., and Camusso, M.: Growth processes of an inland Antarctic ice wedge, Mesa Range, northern Victoria Land, Ann. Glaciol., 39, 379-385, doi:10.3189/172756404781814195, 2004.

Raynaud, D., Delmas, D., Ascencio, J. M., and Legrand, M.: Gas extraction from polar ice cores: a critical issue for studying the evolution of atmospheric $\mathrm{CO}_{2}$ and ice-sheet surface elevation, Ann. Glaciol., 3, 265-268, 1982.

Raynaud, D., Chapellaz, J., Barnola, J. M., Korotkevich, Y., and Lorius, C.: Climatic and $\mathrm{CH}_{4}$ cycle implications of glacialinterglacial $\mathrm{CH}_{4}$ change in the Vostok ice core, Nature, 333, 655657, 1988

Rinke, A., Dethloff, K., Spekat, A., Enke, W., and Hesselbjerg Christensen, J.: High resolution climate simulations over the Arctic, Polar Res., 18, 2, 1999, Special issue: Proceedings of the International Symposium on Polar Aspects of Global Change, available at: http://www.polarresearch.net/index.php/ polar/article/view/6567, 1999.

Romanosky, N. N.: The scheme of correlation of polygonal wedge structures, Biuletyn Peryglacjalny, 26, 287-294, 1976.
Samyn, D., Fitzsimons, S., and Lorrain, R.: Strain-induced phase changes within cold basal ice from Taylor Glacier, Antarctica, indicated by textural and gas analyses, J. Glaciol., 51, 611-619, 2005.

Schirrmeister, L., Siegert, C., Kuznetsova, T., Kuzmina, S., Andreev, A., Kienast, F., Meyer, H., and Bobrov, A.: Paleoenvironmental and paleoclimatic records from permafrost deposits in the Arctic region of Northern Siberia, Quatern. Int., 89, 97-118, 2002.

Schirrmeister, L., Grosse, G., Kunitsky, V., Magens, D., Meyer, H., Dereviagin, A., Kuznetsova, T., Andreev, A., Babiy, O., Kienast, F., Grigoriev, M., Overduin, P. P. and Preusser, F.: Periglacial landscape evolution and environmental changes of Arctic lowland areas for the last 60,000 years (Western Laptev Sea coast, Cape Mamontov Klyk), Polar Res., 27, 249-272, 2008.

Schwamborn, G., Meyer, H., Fedorov, G., Schirrmeister, L., and Hubberten, H.-W.: Ground ice and slope sediments archiving late Quaternary paleoenvironment and paleoclimate signals at the margins of El'gygytgyn Impact Crater, NE Siberia, Quaternary Res., 66, 259-272, doi:10.1016/j.yqres.2006.06.007, 2006.

Souchez, R. and Lorrain, R.: Ice Composition and Glacier Dynamics, Springer-Verlag, 1991.

Souchez, R., Janssens, L., Lemmens, M., and Stauffer, B.: Very low oxygen concentration in basal ice from Summit, Central Greenland, Geophys. Res. Lett., 22, 2001-2004, 1995.

Souchez, R., Jouzel, J., Landais, A., Chapellaz, J., Lorrain, R., and Tison, J.-L.: Gas isotopes in ice reveal a vegetated central Greenland during ice sheet invasion, Geophys. Res. Lett., 33, L24503, doi:10.1029/2006GL028424, 2006.

Stenni, B., Masson-Delmotte, V., Johnsen, S., Jouzel, J., Longinelli, A., Monnin, E., Röthlisberger, R., and Selmo, E.: An Oceanic Cold Reversal During the Last Deglaciation, Science, 293, 2074 2077, 2001.

Stenni, B., Jouzel, J., Masson-Delmotte V., Röthlisberger, R., Castellano, E., Cattani, O., Falourd S., Johnsen, S. J., Longinelli, A., Sachs, J. P., Selmo, E., Souchez, R., Steffensen, J. P., and Udisti, R.: A late-glacial high-resolution site and source temperature record derived from the EPICA Dome $\mathrm{C}$ isotope records (East Antarctica), Earth Planet. Sc. Lett., 217, 183-195, 2004.

Steven, B., Pollard, W. H., Greer, C. W., and Whyte, L. G.: Microbial diversity and activity through a permafrost/ground ice core profile from the Canadian high Arctic, Environ. Microbiol., 10, 3388-3403, doi:10.1111/j.1462-2920.2008.01746.x, 2008.

St-Jean, M., Lauriol, B., Clark, I. D., Lacelle, D., and Zdanowicz, C.: Investigation of ice-wedge infilling processes using stable oxygen and hydrogen isotopes, crystallography and occluded gases $\left(\mathrm{O}_{2}, \mathrm{~N}_{2}\right.$, Ar), Permafrost Periglac. Process., 22, 49-64, doi:10.1002/ppp.680, 2011.

Tison, J.-L.: Diamond-wire saw cutting technique for investigating textures and fabrics of debris-laden ice and brittle ice, J. Glaciol., 40, 410-414, 1994.

Vaikmäe, R.: Oxygen isotopes in permafrost and ground ice - a new tool for paleoclimatic investigations, Leipzig, 1989.

Vasil'chuk, Y. K. and Vasil'chuk, A. C.: Oxygen-isotope and $\mathrm{C}^{14}$ data associated with Late Pleistocene syngenetic ice-wedges in mountains of Magadan region, Siberia, Permafrost Periglac., 9, 177-183, 1998.

Vimeux, F., Masson-Delmotte, V., Jouzel, J., Stiévenard, M., and Petit, J. R.: Glacial-interglacial changes in ocean surface condi- 
tions in the southern Hemisphere, Nature, 398, 410-413, 1999.

Vimeux, F., Cuffey, K., and Jouzel, J.: New insights into Southern Hemisphere temperature changes from Vostok ice cores using deuterium excess correction over the Last 420,000 Years, Earth Planet. Sc. Lett., 203, 829-843, 2002.

Wagner, D. and Liebner, S.: Global warming and carbon dynamics in permafrost soils: Methane production and oxidation, in: Permafrost Soils, edited by: Margesin, R., 219-236, Springer Berlin Heidelberg, 2009.

Wetterich, S., Kuzmina, S., Andreev, A. A., Kienast, F., Meyer, H., Schirrmeister, L., Kuznetsova, T., and Sierralta, M.: Palaeoenvironmental dynamics inferred from late Quaternary permafrost deposits on Kurungnakh Island, Lena Delta, Northeast Siberia, Russia, Quaternary Sci. Rev., 27, 1523-1540, 2008.
Wetterich, S., Rudaya, N., Tumskoy, V., Andreev, A. A., Opel, T., Schirrmeister, L., and Meyer, H.: Last Glacial Maximum records in permafrost of the East Siberian Arctic, Quaternary Sci. Rev., 30, 3139-3151, doi:10.1016/j.quascirev.2011.07.020, 2011.

Yershov, E. D.: Geokryologija SSSR (Geocryology of the USSR), Nedra, Moscow, 1989.

Yurtsever, Y. and Gat, J. R.: Atmospheric waters, in: Stable Isotope Hydrology: Deuterium and Oxygen in Water Cycle, edited by: Rep, T., 103-145, IAEA, Vienna, 1981. 